\title{
PERAN PEMERINTAH DALAM PEMBERDAYAAN PEREMPUAN MELALUI CORPORATE SOCIAL RESPONSIBILITY (CSR)
}

\author{
Ine Mariane \\ Prodi Administrasi Publik, FISIP, Universitas Pasundan \\ Bandung, Jawa Barat, Indonesia \\ ine.mariane@unpas.ac.id
}

\begin{abstract}
ABSTRAK
Penelitian ini adalah bagian dari penelitian yang bertujuan menganalisis bagaimana peran pemerintah dalam pelaksanaan Corporate Social Responsibility (CSR) untuk pemberdayaan perempuan yang berkelanjutan oleh PT. Telkom, Indonesia Tbk di Kecamatan Kiaracondong Kota Bandung. Penelitian menggunakan metode deskriptif kualitatif. Informan dipilih secara purposive yang meliputi perwakilan perusahaan, masyarakat penerima program, dan aparat pemerintah lokal. Teknik pengumpulan data dilakukan melalui serangkaian wawancara mendalam, observasi lapangan dan studi dokumentasi. Penelitian menemukan bahwa pemerintah belum sepenuhnya melaksanakan perannya dalam pelaksanaan CSR untuk pemberdayaan perempuan sehingga dari pelaksanaannya belum menunjukkan keberhasilan dan berdampak pada manfaat yang dirasakan oleh masyarakat yang tercermin pada empowerment index. Berdasarkan hasil penelitian direkomendasikan agar pemerintah mewujudkan networking goverment.
\end{abstract}

Kata Kunci: Peran Pemerintah, Tanggung Jawab Sosial Perusahaan, Empowerment Index.

\section{ABSTRACT}

This research is part of a study that aims to analyze the role of the government in implementing Corporate Social Responsibility (CSR) for sustainable women's empowerment by PT. Telkom, Indonesia Tbk in Kiaracondong District, Bandung City. The research used a qualitative descriptive method. Informants were selected purposively, including company representatives, program recipient communities, and local government officials. The data collection technique was carried out through a series of in-depth interviews, field observations and documentation studies. The study found that the government has not fully carried out its role in implementing CSR for women's empowerment so that its implementation has not shown success and has had an impact on the benefits felt by the community as reflected in the empowerment index. Based on the research results, it is recommended that the government realize networking government.

Keywords: The Role of Government, Corporate Social Responsibility, Empowerment Index.

\section{PENDAHULUAN}

Data jumlah penduduk miskin di Indonesia menunjukkan peningkatan dari tahun ke tahun, tahun 2014 mencapai 27,73 juta orang $(10,96 \%)$ dari total penduduk. Jumlah tersebut bertambah menjadi sebanyak 28,59 juta orang (11,22\%) dari total penduduk pada tahun 2015.(BPS, 2015). Agar jumlahnya tidak semakin membesar, peningkatan jumlah penduduk miskin ini memerlukan penanganan, karena jika tidak ditangani dapat menjadi masalah kesejahteraan sosial. Penanganan masalah kemiskinan maupun masalah-masalah kesejahteraan sosial lainnya selain menjadi tanggung jawab pemerintah juga menjadi tanggung jawab bersama, dalam hal ini diperlukan partisipasi baik dari masyarakat - termasuk masyarakat akademisi maupun dunia usaha. Hal tersebut tercermin dari upaya pemerintah dalam menekan angka kemiskinan dan meningkatkan kesejahteraan sosial, juga melibatkan unsur dunia usaha. Perusahaan sebagai salah satu aktor dalam penyelenggaraan kesejahteraan sosial melaksanakannya melalui CSR, yang turut diamanatkan dalam Undang-Undang nomor 40/2007 tentang Perseroan Terbatas pasal 74 (1) bahwa perseroan yang menjalankan kegiatan 


\section{Kebijakan: Jurnal Ilmu Administrasi \\ Volume 11, Nomor 1, Januari 2020 \\ E-ISSN: 2656-2820 \\ P-ISSN 1829-5762}

usahanya di bidang dan/atau berkaitan dengan sumber daya alam wajib melaksanakan tanggung jawab sosial dan lingkungan. Dunia usaha dimaksud adalah perusahaan dalam bentuk perseroan terbatas baik Badan Usaha Milik Negara (BUMN), Badan Usaha Milik Daerah (BUMD), perusahaan swasta, maupun perusahaan multinasional. Hal ini tertuang dalam Undang-Undang nomor 11/2009 tentang Kesejahteraan Sosial pasal 40, yang menyatakan bahwa peran badan usaha dalam penyelenggaraan kesejahteraan sosial dilakukan sebagai tanggung jawab sosial, terutama dalam penanganan masalah kesejahteraan sosial, diantaranya adalah masalah kemiskinan.

Hal ini didukung pula oleh beragam upaya Pemerintah Provinsi, Kabupaten dan Kota untuk menerbitkan peraturan terkait pelaksanaan CSR. Salah satunya adalah Pemerintah Provinsi Jawa Barat dengan menerbitkan Peraturan Gubernur Jawa Barat Nomor 30 Tahun 2011 tentang Fasilitasi Penyelenggaraan Tanggung Jawab Sosial dan Lingkungan di Jawa Barat guna memfasilitasi sinergitas dan koordinasi pelaksanaan CSR dalam menunjang pembangunan untuk meningkatkan kesejahteraan masyarakat. Fasilitasi dimaksud diantaranya dalam penunjukan perusahaan yang disarankan untuk memberikan bantuan kepada masyarakat. Gubernur Jawa Barat juga meminta kepada BUMD untuk memperluas cakupan dan CSR agar bisa meningkatkan sektor kesehatan, pendidikan dan pemberdayaan masyarakat sehingga dapat meningkatkan kesejahteraan warga di Jawa Barat (Pikiran Rakyat, 27 Juni 2015:7). Tanggung jawab sosial perusahaan dalam pelaksanaannya memerlukan dukungan stakeholders berupa kerja sama baik dengan pemerintah maupun akademisi. Hasil penelitian Saat ini kontribusi dunia usaha melalui CSR dalam penyelenggaraan kesejahteraan sosial di Indonesia cukup besar, hal ini dapat dilihat dari tingginya kepedulian dunia usaha khususnya BUMN terhadap upaya-upaya peningkatan kesejahteraan sosial bagi penyandang masalah kesejahteraan sosial, baik dalam bentuk charity maupun community development (CSRKESOS, April 2014).

Perusahaan berbentuk Badan Usaha Milik Negara (BUMN) telah melaksanakannya sejak diberlakukannya Undang-Undang no. 19/2003 tentang Badan Usaha Milik Negara, diikuti dengan Keputusan Menteri BUMN Nomor Kep -236 /MBU/2003 Tentang Program kemitraan Badan Usaha Milik Negara Dengan Usaha Kecil Dan Program Bina Lingkungan. Salah satu perusahaan yang telah melaksanakan CSR adalah PT. Telekomunikasi Indonesia, Tbk yang merupakan salah satu Badan Usaha Milik Negara (BUMN) yang berkomitmen melaksanakan good corporate governance secara konsisten agar senantiasa memberikan layanan terbaik dan menjaga kepercayaan dari masyarakat. Kegiatan CSR yang dilaksanakan diharapkan berdampak jangka panjang (sustainable) baik bagi masyarakat maupun bagi perusahaan. Salah satu penerima bantuan pada program bina lingkungan di Kota Bandung adalah masyarakat di Kelurahan Sukapura Kecamatan Kiaracondong, Kota Bandung. Dimana kondisi sosial ekonomi masyarakatnya masih banyak dalam kondisi miskin. Kelurahan Sukapura Kecamatan Kiaracondong menjadi perhatian PT. Telkom untuk diberikan bantuan berupa kegiatan pemberdayaan perempuan dalam Program Bina Lingkungan (PBL) sebagai community development. Untuk keberhasilan pelaksanaan CSR dalam meningkatkan kesejahteraan masyarakat, selain peran pemerintah juga diperlukan adanya partisipasi akademisi, sehingga ketiga unsur tersebut dapat bekerja sama dalam pelaksanaan CSR.

Berdasarkan hal tersebut maka pertanyaan penelitian (research questions) yang diajukan adalah "Bagaimanakah peran pemerintah dalam pemberdayaan perempuan melalui pelaksanaan CSR oleh PT. Telkom di Kecamatan Kiaracondong Kota Bandung?

\section{a. Kepentingan dan peran pemerintah terhadap isu CSR}

Steurer (2009) memberikan beberapa alasan kenapa pemerintah memiliki kepentingan di dalam isu CSR. Pertama hal tersebut sejalan dengan konsep pembangunan berkelanjutan (sustainable development). Motivasi pertama ini berkaitan dengan politik luar negeri seperti 


\section{Kebijakan: Jurnal Ilmu Administrasi \\ Volume 11, Nomor 1, Januari 2020 \\ E-ISSN: 2656-2820 \\ P-ISSN 1829-5762}

program pengembangan sumber daya manusia (human development program). Alasan kedua adalah, kebijakan CSR dianggap sebagai pelengkap yang menarik dalam peraturan yang lain misal di Indonesia dalam undang-undang Perseroan Terbatas, dalam hal ini pemerintah dapat menunjukkan kepeduliaanya pada isu sosial dan lingkungan meskipun peraturan tentang tanggung jawab sosial perusahaan ini hanya mendapatkan porsi yang sangat sedikit didalam undang-undang tersebut. Ketiga adalah, pelaksanaan CSR masih sebatas pada asas sukarela (voluntary basis) sehingga pemerintah perlu memberikan penekanan agar pelaksanaan CSR lebih mendapat fokus perhatian dari perusahaan. Alasan keempat adalah, banyak pendekatan dalam pelaksanaan CSR menggunakan konsep partnership program (program kemitraan) sehingga akan membuka potensi keterlibatan masyarakat secara luas dalam pembangunan berkelanjutan. Hal ini sangat berkaitan dengan pengelolaan hubungan dan peran dengan pemangku kepentingan secara luas misalnya bisnis, pemerintah dan masyarakat sipil.

Menurut Fox et al. (2002) Bank Dunia telah memberikan kategori peran pemerintah dalam mensupport CSR ke dalam lima kategori seperti dalam tabel 1. Fox et al (2002) mendeskripsikan peran sektor publik yang dapat di adopsi oleh pemerintah dalam isu CSR yaitu mandatory (peran legislasi), facilitating (missal; petunjuk dalam hal konten pelaporan CSR), partnering (proses penguatan dengan multi-stakeholder), dan endorsing (publikasi dan pemberian penghargaan).

Tabel 1. Peran sektor publik dalam CSR

\begin{tabular}{|c|ccc|}
\hline \multicolumn{4}{|c|}{ Public Sector Roles } \\
\hline Mandating & $\begin{array}{c}\text { 'Command and control' } \\
\text { legislation }\end{array}$ & $\begin{array}{c}\text { Regulators and } \\
\text { inspectorates }\end{array}$ & $\begin{array}{c}\text { Legal and fiscal } \\
\text { penalties and rewards }\end{array}$ \\
\hline Facilitating & 'Enabling' legislation & Creating incentives & Capacity building \\
\cline { 2 - 4 } & Funding support & Raising awareness & Stimulating markets \\
\hline Partnering & Combining resources & $\begin{array}{c}\text { Stakeholder } \\
\text { engagement }\end{array}$ & Dialogue \\
\hline Endorsing & Political support & & Publicity and praise \\
\hline
\end{tabular}

O'Rouke (2004) memberikan penjelasan lebih detail tentang kategori peran pemerintah diatas. Pertama, peran mandating adalah ketika pemerintah secara legal memeberikan mandat melalui undangundang atau peraturan pemerintah. Sehingga pemerintah dapat melakukan pengawasan dari segi pelaporan CSR baik evaluasi laporan maupun melakukan cross check terhadap isi laporan. Kedua adalah facilitating ketika pemerintah memberikan suatu rujukan atau guidelines dalam pelaksanaan maupun pelaporan CSR dan penyebarluasan informasi CSR. Ketiga adalah partnering yang mana pemerintah terlibat dalam proses promosi inisiatif kerjasama multi-stakeholder atau kerjasama dengan masing-masing perusahaan. Dengan kata lain pemerintah dapat menjadi fasilitator dialog antar pemangku kepentingan. Keempat adalah peran endorsing dalam hal pelaporan program CSR melalui usaha yang positif dalam kerangka transparansi sebagai contoh adalah pemberian penghargaan CSR Pemerintah Indonesia melalui undang-undang Perseroan Terbatas UU No 40 Tahun 2007 menginsyaratkan bahwa secara eksplisit peran yang dilakukan pemerintah adalah pada peran"mandating'. Peran mandating yang dilakukan pemerintah juga tercermin pada peraturan Menteri Negara Badan Usaha Milik Negara (BUMN) Nomor Per 05/MBU/2007 tentang Program Kemitraan BUMN dengan Usaha Kecil Menengah (UKM) dan Program Bina Lingkungan (BL). Program Kemitraan BUMN dengan Usaha Kecil yang disebut Program Kemitraan, adalah program untuk meningkatkan kemampuan usaha kecil agar menjadi tangguh dan mandiri. Sedangkan Program Bina Lingkungan yang disebut Program BL adalah program pemberdayaan kondisi sosial masyarakat 


\section{Kebijakan: Jurnal Ilmu Administrasi \\ Volume 11, Nomor 1, Januari 2020 \\ E-ISSN: 2656-2820 \\ P-ISSN 1829-5762}

oleh BUMN. Keduanya dilaksanakan melalui pemanfaatan dana dari bagian laba BUMN yang secara perturan menyebutkan bahwajumlah penyisihan laba untuk pendanaan program maksimal sebesar $2 \%$ (dua persen) dari laba bersih untuk Program Kemitraan dan maksimal 2\% (dua persen) dari laba bersih untuk Program Bina Lingkungan. Ruang lingkup bantuan Program BL BUMN meliputi bantuan korban bencana alam, bantuan pendidikan dan/atau pelatihan, bantuan peningkatan kesehatan, bantuan pengembangan prasarana dan/atau sarana umum, bantuan sarana ibadah dan bantuan pelestarian alam.

\section{b. Konsep Corporate Social Responsibility (CSR)}

Kotler (2005:4), mengemukakan bahwa CSR menjadi bagian dari komitmen perusahaan untuk meningkatkan kesejahteraan komunitas melalui praktik bisnis yang baik dan mengkontribusikan sebagian sumber daya perusahaan. Pernyataan serupa dikemukakan pula oleh Rudito et.al (2004:72), Sri Pambudi (2005:18) dan Suharto (2009:102). Sejalan dengan itu Suharto (2009:103). mengungkapkan pula pendapat Schemerson bahwa Corporate social responsibility (CSR) sebagai suatu kepedulian organisasi bisnis untuk bertindak dengan cara-cara mereka sendiri dalam melayani kepentingan organisasi dan kepentingan publik eksternal. Secara konseptual CSR adalah sebuah pendekatan dimana perusahaan mengintegrasikan kepedulian sosial dalam operasi bisnis mereka dan dalam interaksi mereka dengan para pemangku kepentingan (stakeholders) berdasarkan prinsip kesukarelaan dan kemitraan.

John Elkington (1998:69) dalam bukunya "Canibals with Forks: The Triple Bottom Line in 21 st Century Business" yang dikutip oleh Wahyudi \& Azheri (2008:140) dan Suharto (2010:5, 125), mengemukakan bahwa secara konseptual CSR merupakan kepedulian perusahaan yang didasari tiga prinsip dasar yang dikenal dengan Triple Bottom Lines (3P): Profit, People, Planet. Ketiga hal tersebut merupakan satu kesatuan aktifitas perusahaan yang dapat dilakukan secara simultan sesuai dengan kondisi sosio kemasyarakatan yang berkembang. Teori ini menegaskan bahwa orientasi perusahaan tidak hanya untuk mencari keuntungan (profit) saja, melainkan juga perusahaan mengupayakan kelestarian dan pengelolaan lingkungan (planet) serta perusahaan mengupayakan kesejahteraan masyarakat (people). Hal ini dapat diartikan bahwa disamping tujuan utamanya mencari keuntungan ekonomi, perusahaan juga bertujuan untuk mencari keuntungan sosial dengan menunjukkan kepeduliannya pada lingkungan sosial berkenaan dengan upaya untuk meningkatkan dampak positif perusahaan dan meningkatkan kualitas hidup masyarakat dengan community development.

\section{c. CSR Melalui Pemberdayaan}

Kegiatan community development diarahkan pada proses pemberkuasaan/ pemberdayaan, peningkatan kekuasaan atau peningkatan kemampuan para penerima bantuan. Hal ini memperkuat pendapat Dubois dalam Shera (1999:2) dan Zastrow (2010:52) bahwa pemberdayaan menyiratkan dua hal, yaitu proses dan tujuan. Pemberdayaan sebagai proses untuk meningkatkan kapasitas individu, keluarga dan masyarakat, sehingga dapat terlibat di lingkungan mereka. Sedangkan pemberdayaan sebagai tujuan adalah suatu hasil akhir dari kegiatan, yakni perolehan kekuatan tertentu. Pemberdayaan masyarakat pada dasarnya merupakan kegiatan terencana dan kolektif dalam memperbaiki kehidupan masyarakat yang dilakukan melalui peningkatan kapasitas orang terutama kelompok lemah atau kurang beruntung (disadvantage groups) agar mereka memiliki kemampuan dalam memenuhi kebutuhan dasarnya, mengemukakan gagasan, melakukan pilihan-pilihan hidup, melaksanakan kegiatan ekonomi, menjangkau dan memobilisasi sumber, dan berpartisipasi dalam kegiatan sosial. Demikian halnya kelompok masyarakat sebagai penerima bantuan dalam penelitian 


\section{Kebijakan: Jurnal Ilmu Administrasi Volume 11, Nomor 1, Januari 2020 E-ISSN: 2656-2820 P-ISSN 1829-5762}

ini adalah sebagaimana dikemukakan Suharto (2007:110) yaitu kelompok masyarakat yang dianggap lemah atau kurang berdaya dalam aspek finansial; yaitu orang yang tidak memiliki pekerjaan, pendapatan, kendala modal dan aset yang mampu menopang kehidupannya.

Ditujukan bagi masyarakat kurang beruntung, pemberdayaan dapat diartikan sebagai suatu proses menuju berdaya atau proses untuk memperoleh daya/kekuatan/kemampuan, dan atau proses pemberian daya dari pihak yang memiliki daya kepada pihak yang kurang atau belum berdaya, yaitu masyarakat yang mengalami kemiskinan atau masyarakat miskin. Anwas (2014:49) mengemukakan mengenai pemberdayaan menurut Djohani (2003) sebagai suatu proses yang memberikan daya/kekuasaan/power kepada pihak yang lemah (powerless), dan mengurangi kekuasaan (disempowered) kepada pihak yang terlalu berkuasa (powerful) sehingga terjadi keseimbangan. Menurut Rappaport (1984) dalam Anwas (2014:49), pemberdayaan adalah suatu cara dengan mana rakyat, organisasi, dan komunitas diarahkan agar mampu menguasai atau berkuasa atas kehidupannya. Anwas (2014:14) mengemukakan pengertian lain dari pemberdayaan, yaitu menurut Parson (1994) dalam pemberdayaan menekankan bahwa orang memperoleh ketrampilan pengetahuan dan kekuasaan yang cukup untuk mempengaruhi kehidupannya dan kehidupan orang lain yang menjadi perhatiannya. Menurut Ife (1995); pemberdayaan adalah menyiapkan kepada masyarakat berupa sumber daya, kesempatan, pengetahuan dan keahlian untuk meningkatkan kapasitas diri masyarakat di dalam menentukan masa depan mereka, serta berpartisipasi dan mempengaruhi kehidupan dalam komunitas masyarakat itu sendiri.

Dengan demikian pemberdayaan merupakan proses sekaligus hasil sebagai tujuan dari pemberdayaan. Hal ini dikemukakan juga oleh Ife (2006:199) bahwa pemberdayaan adalah pemberian kekuasaan kepada individu dan kelompok untuk memiliki atau menggunakan kesempatan untuk meraih kekuasaan ke dalam tangan mereka, meredistribusi kekuasaan dari orang yang punya kepada orang yang tidak berpunya. Demikian halnya menurut Barker dan Zastrow (2010:52) bahwa pemberdayaan adalah proses pertolongan pada individu, kelompok ataupun komunitas hubungan personal dan interpersonal dan kekuatan politik, sosial ekonomi, serta ditujukan untuk meningkatkan pengaruh pada lingkungan mereka. Demikian juga menurut Dubois dalam Shera (1992:2) bahwa pemberdayaan menyiratkan pada proses dan hasil. Sebagai proses pemberdayaan utnuk meningkatkan kekuatan pada diri individu dan antar personal, sehingga individu, keluarga, dan masyarakat dapat terlibat di lingkungan mereka. Sebagai tujuan, pemberdayaan adalah suatu ungkapan akhir, yakni perolehan kemampuan tertentu.

Berdasarkan itu dimensi pemberdayaan dapat ditinjau dari proses pelaksanaan kegiatan, dan dampak dari CSR.

1. Sebagai proses pelaksanaan kegiatan;

2. Sebagai dampak kegiatan;

Sebagaimana dikemukakan oleh Ghana, Lord Holme dan Richard Watts yang dikutip oleh Nor Hadi (2010:46) bahwa "CSR adalah tentang peningkatan kapasitas yang berkelanjutan, yang menghormati perbedaan budaya dan peluang bisnis dalam membangun keterampilan karyawan, masyarakat, dan pemerintah".

Mengenai hal tersebut sebagai dampak kegiatan dikemukakan oleh Schuler, Hashemi dan Riley dalam Suharto (2010:64) yang mengaitkan dengan prinsip pemberdayaan, bahwa keberlanjutan sosial dapat ditinjau dari indeks pemberdayaan yang disebut sebagai empowerment index, yang meliputi:

1. Berkurangnya ketergantungan dan berkembangnya kemandirian

2. Utilitas dan konsumsi tidak berkurang sepanjang waktu (non declining consumption). 


\section{Kebijakan: Jurnal Ilmu Administrasi \\ Volume 11, Nomor 1, Januari 2020 \\ E-ISSN: 2656-2820 \\ P-ISSN 1829-5762}

3. Mampu mencapai kesetaraan dan mencapai penyediaan layanan sosial seperti kesehatan dan pendidikan.

4. Memiliki kebebasan mobilitas; merupakan kemampuan individu untuk pergi ke luar rumah atau wilayah tempat tinggalnya.

5. Kemampuan membeli komoditas kecil dan atau komoditas besar.

6. Terlibat dalam pembuatan keputusan rumah tangga.

7. Meningkatkan interaksi antar kelompok.

8. Meningkatkan kerekatan sosial, kerja sama, rasa keakraban, kekompakan, saling percaya, dan saling mendukung antar kelompok masyarakat.

\section{METODE}

Metode yang digunakan dalam penelitian ini adalah metode kualitatif, yakni bentuk penelitian yang berusaha membangun makna tentang suatu fenomena berdasarkan pandangan-pandangan dari partisipan (Creswell, 201024), dengan studi deskriptif yang bertujuan untuk memberikan gambaran tentang suatu fenomena secara detail (untuk menggambarkan apa yang terjadi), yaitu mengungkapkan fenomena tentang pelaksanaan CSR melalui pemberdayaan masyarakat. Pendekatan kualitatif yang dilakukan berupaya mengungkap dan memberikan gambaran secara menyeluruh atas hasil yang diperoleh dari wawancara dan pengumpulan data untuk memahami pelaksanaan CSR dengan memposisikan perusahaan sebagai subjek penelitian dan pelaksana utama dalam keseluruhan proses. Langkah pertama untuk menetapkan informan adalah mencari informan kunci (key person) yang dijadikan petunjuk untuk mendapatkan data dan informasi yang diperlukan, yakni Manager Corporate Development Regional III Jawa Barat PT. Telkom Indonesia, Tbk. Dari informan kunci didapatkan informasi yang akurat tentang pelaksanaan CSR PT. Telkom, sehingga dapat mengidentifikasi beberapa karakteristik informan untuk mendapatkan data sesuai dengan kebutuhan penelitian. Informan ditentukan secara purposive, yang diselaraskan dengan objek penelitian meliputi :

1. Pemerintah Kelurahan Sukapura Kecamatan Kiaracondong, Kota Bandung

2. Manager Corporate Development Area PT. Telkom Indonesia ,Tbk Regional Jawa Barat

3. Masyarakat di Kecamatan Kiaracondong Kota Bandung yang menjadi sasaran program bina lingkungan.

Pengumpulan data menggunakan :

1. Wawancara mendalam (indepth interview)

2. Observasi;

3. Studi Dokumentasi

Instrumen penelitian adalah peneliti sendiri, dimana peneliti berfungsi menetapkan fokus penelitian, memilih informan sebagai sumber data, menilai kualitas data, analisis data, menafsirkan data, dan membuat kesimpulan atas temuannya.

\section{PEMBAHASAN}

Aspek ini berkaitan dengan kegiatan-kegiatan yang menunjang bidang kemasyarakatan, khususnya pengembangan masyarakat. Kegiatan CSR PT. Telkom yang dilaksanakan di Kecamatan Kiaracondong Kota Bandung dalam realisasi Program Bina Lingkungan adalah pengembangan masyarakat dalam bentuk pemberdayaan perempuan.

\section{a. Proses Pelaksanaan Kegiatan Pemberdayaan Perempuan \\ 1. Program Berjalan Secara berkesinambungan}




\section{Kebijakan: Jurnal Ilmu Administrasi \\ Volume 11, Nomor 1, Januari 2020 \\ E-ISSN: 2656-2820 \\ P-ISSN 1829-5762}

Proses pelaksanaan program bina lingkungan PT. Telkom secara umum melalui proses penyaluran proaktif. Bahwa penyaluran bantuan untuk program bina lingkungan diberikan setelah mendapat permohonan dari masyarakat baik melalui usulan proposal maupun diusulkan oleh pihak tertentu. Setelah adanya pengajuan atau diusulkan, perusahaan menindaklanjuti dengan melaksanakan survey dan mapping ke lokasi pemohon untuk kemudian dilakukan wawancara intensif, baik dengan masyarakat sekitar maupun pemerintahan setempat/ kelurahan, untuk kemudian dilakukan penandatanganan sebagai bukti telah dilaksanakan survey. Data dari survey tersebut diperlukan sebagai bahan pertimbangan kelayakan pemohon/ yang diusulkan untuk menerima bantuan. Setelah melalui kajian di perusahaan, masyarakat Kelurahan Sukapura ditetapkan sebagai penerima bantuan pada program BUMN Membangun Desa, yang dilaksanakan pada tahun 2013 bersamaan dengan Desa/Kelurahan lain di seluruh Indonesia. Penerima bantuan di Kecamatan Kiaracondong diwakili oleh LPM Rumah Iqro sebagai penyelenggara kegiatan pemberdayaan perempuan. Pemanfaatan bantuan dijalankan dengan baik oleh masyarakat bersama-sama dengan pengurus dengan kegiatan pelatihan tata boga dan tata busana, sehingga peserta mendapatkan ketrampilan sesuai dengan minat masing-masing. Agar program ini berdampak secara berkelanjutan, perusahaan memberikan kesempatan kepada peserta pelatihan yang sudah memiliki keterampilan untuk mendapatkan pinjaman bergulir dari perusahaan untuk dijadikan modal awal apabila peserta bermaksud membuka usaha dari keterampilannya.

\section{Ada Disain Program Yang Terencana}

Anwas (2014:150) mengemukakan bahwa realitas dalam masyarakat atau keluarga miskin biasanya sumber penghasilan keluarga mengandalkan suami. Peran istri terbatas mengurus anak atau rumah tangga di rumah. Padahal keluarga kurang beruntung itu umumnya berpendidikan rendah dan ketrampilan rendah. Kondisi demikian menyebabkan semakin tidak berdaya akibat mereka tidak memiliki modal usaha apalagi jaringan (networking) untuk mengembangkan usaha ekonomi keluarganya. Untuk membantu keluarga demikian diperlukan peranserta perempuan. Para istri dari keluarga miskin perlu diberdayakan untuk membantu suaminya dalam mencari nafkah keluarganya. Manakala hanya mengandalkan suami dalam mencari penghasilan yang memiliki ketrbatasan dalam modal, kemampuan, pengalaman dan juga networking sulit untuk mampu meningkatkan ekonomi keluarga. Apabila istri dan suami bersatu dalam mencari nafkah keluarga berarti menyatukan dua kekuatan. Dua kekuatan yang disatukan ini akan menjadi dorongan yang kuat untuk meningkatkan ekonomi dan kesejahteraan keluarga. Hal itu dikatakan sebagai pemberdayaan perempuan.

Pemberdayaan Perempuan di Kecamatan Kiaracondong merupakan bagian dari Program "BUMN Membangun Desa" yang merupakan serangkaian kegiatan pelatihan ketrampilan bagi komunitas perempuan dalam bentuk pelatihan tata boga, tata busana dan pengembangan keterampilan remaja putri dan anak-anak putus sekolah. Masyarakat Kecamatan Kiaracondong khususnya Kelurahan Sukapura merupakan masyarakat dalam status sosial ekonomi yang lemah. Karenanya diperlukan penguatan-penguatan agar memiliki keberdayaan dengan melalui serangkaian kegiatan pemberdayaan perempuan melalui pelatihan ketrampilan perempuan; tata busana dan tata boga agar dapat berkegiatan secara produktif, dan menambah penghasilan keluarga. Program didisain secara terencana dengan adanya pendampingan yang direncanakan dilakukan dalam kegiatan pemanfaatan bantuan sehingga program yang digulirkan bisa berjalan secara maksimal.

\section{Termonitoring dan Evaluasi}

Monitoring pada kegiatan pemberdayaan perempuan adalah atas partisipasi pemerintahan setempat khususnya Kepala Kelurahan Sukapura, masyarakat, dan terutama dilakukan oleh Ketua PKK. Meskipun tidak dilaksanakan secara rutin melalui agenda khusus, namun pemerintahan 


\section{Kebijakan: Jurnal Ilmu Administrasi Volume 11, Nomor 1, Januari 2020 E-ISSN: 2656-2820 P-ISSN 1829-5762}

setempat memfasilitasi LPM "Rumah Iqra" untuk berkomunikasi mengenai kegiatan yang dilaksanakan sekaligus sebagai monitoring kegiatan. Sehingga kegiatan pemberdayaan perempuan dapat terlaksana secara lancar, pula dengan memanfaatkan bantuan perlengkapan yang diterima dari PT. Telkom. Hal-hal yang menjadi perhatian dalam monitoring tersebut difokuskan pada keberlangsungan kegiatan baik tata busana maupun tata boga. Pada program bina lingkungan, setelah dilaksanakan pemberian bantuan, secara formal PT. Telkom tidak melakukan pemantauan (monitoring) pada pelaksanaan kegiatan pemanfaatan bantuan perlengkapan untuk pemberdayaan perempuan. Bahkan penerima bantuan tidak dituntut untuk melaksanakan pelaporan. Namun secara informal ada petugas yang berinisiatif melakukan monitoring ke lokasi penerima bantuan. Sesudah dilakukan triangulasi data terhadap informan dari PT. Telkom, perusahaan memberikan kepercayaan sepenuhnya kepada masyarakat penerima bantuan dan pemerintahan setempat untuk monitoring dan evaluasi. PT. Telkom percaya, dengan karakteristik masyarakat setempat, mereka akan memanfaatkan bantuan dengan penuh tanggung jawab. Dan dikarenakan dana yang digunakan merupakan dana hibah, maka tidak diperlukan pertanggungjawaban atas pemanfaatan bantuannya. Meskipun demikian penerima bantuan memberikan laporan pemanfaatan dan perkembangan kegiatan sebagai pertanggungjawaban atas bantuan yang diterimanya. Sehingga dari laporan pertanggungjawaban itu PT. Telkom dapat melakukan evaluasi atas pemanfaatan bantuan perlengkapan pemberdayaan perempuan yang diberikan kepada masyarakat kecamatan Kiaracondong.

Pentingnya monitoring dikemukakan oleh Marjuki dan Suharto (2010:118) yang merupakan pemantauan secara terus-menerus proses perencanaan dan pelaksanaan kegiatan, dengan cara mengikuti langsung kegiatan atau membāca hasil laporan dari pelaksanaan kêgiatan. Monitoring adalah proses pengumpulan informasi mengenai apa yang sebenarnya terjadi selama proses implementasi atau penerapan program. Tujuannya adalah:

1. Mengetahui bagaimana masukan (inputs) sumber-sumber dalam rencana digunakan.

2. Bagaimana kegiatan-kegiatan dalam implementasi dilaksanakan.

3. Apakah rentang waktu implementasi terpenuhi secara tepat atau tidak.

4. Apakah setiap aspek dalam perencanaan dan implementasi berjalan sesuai dengan yang diharapkan.

Evaluasi merupakan tahap akhir dari proses pelaksanaan kegiatan dalam pekerjaan sosial, dilaksanakan untuk mengetahui sejauh mana program mencapai tujuan, dan sebagai pertanggungjawaban atas dana yang telah dikeluarkan oleh perusahaan dalam kegiatan yang telah dilakukan. Tahap evaluasi digunakan untuk menguji keampuhan dan ketepatan alternatif intervensi yang diterapkan, juga memonitor faktor yang membawa keberhasilan dan yang mengakibatkan kegagalan. Delgado (2000:206) mengemukakan, "evaluation should never be viewed as the final phase. the result gathered through evaluation will prove of immeasurable aid in helping social workers and communities develop more efficient and sustainable enhancement projects. Evaluation must highlights the successes and failures and provide sufficient data to allow for corrections in future endeavors". Hasil yang dikumpulkan melalui evaluasi akan membuktikan bantuan beragam dalam membantu pekerja sosial dan masyarakat mengembangkan proyek-proyek peningkatan lebih efisien dan berkelanjutan. Evaluasi harus menyoroti keberhasilan dan kegagalan dan menyediakan data yang cukup untuk memungkinkan koreksi di masa depan usaha.

Pentingnya tahap evaluasi yang dilaksanakan adalah untuk mengetahui sejauhmana program bina lingkungan mencapai tujuan, dan sebagai pertanggungjawaban atas dana yang telah dikeluarkan oleh perusahaan dalam kegiatan yang telah dilakukan. Evaluasi merupakan unsur penting dalam 


\section{Kebijakan: Jurnal Ilmu Administrasi \\ Volume 11, Nomor 1, Januari 2020 \\ E-ISSN: 2656-2820 \\ P-ISSN 1829-5762}

proses pertolongan, karena memungkinkan bagi pelaksana kegiatan untuk memberikan respon dan pertanggungjawaban baik kepada perusahaan maupun penerima bantuan. Tahap ini juga digunakan untuk menguji keampuhan dan ketepatan alternatif intervensi yang diterapkan, juga memonitor faktor yang membawa keberhasilan dan yang mengakibatkan kegagalan. Bahkan Cummins (2011:379) mengemukakan 3 (tiga) tipe evaluasi yaitu 1) Evaluasi proses/ formatif; Berkaitan dengan proses pengembangan, implementasi, dan penyampaian layanan program kesejahteraan sosial. Evaluasi formatif pada umumnya dilakukan dengan tujuan memperbaiki implementasi kebijakan dan program sehingga tujuan kebijakan dapat tercapai. 2) Evaluasi sumatif atau hasil; Berkaitan dengan hasil yang dapat dicapai oleh sebuah kebijakan dan programnya. Jenis evaluasi ini dapat berfokus pada sejauh mana tujuan kebijakan telah tercapai, sejauh mana masalah sosial telah dikurangi, atau jumlah dan kualitas layanan yang diberikan. 3) Evaluasi biaya / manfaat; Biasanya digunakan untuk menilai efektivitas program. Jenis ini berkaitan dengan biaya penerapan kebijakan, dan memberikan layanan kepada populasi sasaran, dibandingkan dengan keuntungan yang diperoleh dari kebijakan dan programnya. Dengan demikian dapat dikatakan bahwa evaluasi tidak hanya dilakukan pada saat sebuah kegiatan selesai dilaksanakan, melainkan evaluasi dilakukan sejak awal pelaksanaan kegiatan. Sesungguhnya tahapan monitoring termasuk dalam salah satu tipe evaluasi tersebut, yakni evaluasi proses/formatif.

\section{b. Dampak Pelaksanaan Kegiatan Pemberdayaan Perempuan}

Keberhasilan pelaksanaan CSR dapat dilihat dari hasil yang diperoleh oleh masyarakat atas bantuan perlengkapan pemberdayaan perempuan. Dengan diperolehnya ketrampilan maka perempuan di Kelurahan Sukapura menjadi berdaya, dalam arti masyarakat menjadi memiliki ketrampilan yang kemudian dikembangkan untuk bisa dimanfaatkan secara produktif guna menambah penghasilan keluarga. Adapun ketrampilan yang diperoleh oleh masyarakat dari kegiatan pemberdayaan perempuan adalah:

1. Memiliki ketrampilan tata boga;

Dengan adanya bantuan dari PT. Telkom berupa perlengkapan membuat kue, yaitu mixer berkapasitas tinggi dan oven berbahan bakar gas, potensi atau minat masyarakat dalam keterampilan membuat kue semakin terfasilitasi dan tergali. Perlengkapan modern dengan kapasitas tinggi ini dapat menghasilkan produksi kue dalam jumlah yang besar, sehingga manakala peserta mendapat pesanan banyak dari luar dapat dikerjakan dalam waktu yang lebih cepat dibandingkan dengan mixer dan oven biasa. Biasanya banyaknya pesanan terjadi pada saat menjelang hari raya dan ketika musim hajatan. Peserta pelatihan tata boga, dengan ketrampilan yang dimiliki mereka dapat membuat kue untuk dijual, baik dikerjakan sendiri maupun bersama-sama dengan sukarela.

2. Memiliki ketrampilan tata busana;

Diperolehnya bantuan membuat warga memiliki ketrampilan menjahit, baik untuk

menjahit pakaian sendiri bahkan dapat dimanfaatkan secara produktif, yaitu dengan mencoba menerima pesanan menjahit pakaian dari orang lain, sehingga lambat laun dengan pengembangan ketrampilan ini informan mendapat upah menjahit dan dapat membantu menambah penghasilan keluarga.

Dengan perlengkapan menjahit berkecepatan tinggi yang modern, produktifitas pengerjaan menjahit menjadi lebih cepat dan lebih banyak. Peserta pelatihan menjahit ada yang mulai menerima pesanan jahitan meskipun tidak memiliki mesin jahit di rumah, namun dikerjakan di Rumah Iqro.

Dampak dari pemberdayaan perempuan adalah berupa keberlanjutan sosial berupa manfaat yang diperoleh oleh masyarakat atas pemanfaatan bantuan yang telah diterima, yang meliputi: 


\section{Kebijakan: Jurnal Ilmu Administrasi \\ Volume 11, Nomor 1, Januari 2020 \\ E-ISSN: 2656-2820 \\ P-ISSN 1829-5762}

1. Berkurangnya ketergantungan dan berkembangnya kemandirian; yakni berkurangnya ketergantungan masyarakat kepada pihak lain secara finansial, karena sudah dapat mengembangkan keterampilan secara produktif melalui usaha tata boga maupun tata busana, serta dapat mengelola usahanya secara mandiri.

2. Utilitas yang diperoleh masyarakat tidak berkurang sepanjang waktu dan konsumsi tidak menurun sepanjang waktu (non declining consumption); manfaat dari bantuan perlengkapan yang diterima oleh masyarakat dirasakan dalam jangka waktu panjang, serta penerima manfaat bertambah banyak sehingga masyarakat memanfaatkannya secara terus menerus hingga dapat memiliki kegiatan usaha dan dapat memenuhi kebutuhan konsumsi baik secara kuantitas maupun kualitas.

3. Mampu mencapai kesetaraan dan mencapai penyediaan layanan sosial seperti kesehatan dan pendidikan. Masyarakat dalam hal ini masyarakat perempuan dapat mengembangkan potensi dan ketrampilan melalui usaha tata boga dan tata busana sehingga mampu mencapai kesetaraan ekonomi dan sosial dengan orang lain. Selain itu dengan pengembangan usaha masyarakat dapat menjangkau layanan-layanan sosial, baik layanan kesehatan maupun layanan pendidikan untuk anak serta mendukung putra putrinya untuk giat belajar.

4. Kebebasan mobilitas; merupakan kemampuan individu untuk pergi ke luar rumah atau wilayah tempat tinggalnya; masyarakat dapat melakukan mobilitas sehubungan dengan diperolehnya penghasilan, sehingga kendala berupa biaya transportasi dapat diatasi, baik mobolitas untuk kepentingan usaha berupa pembelanjaan bahan usaha, mengantar pesanan, maupun dalam kepentingan pribadi.

5. Kemampuan membeli komoditas kecil dan atau komoditas besar;

Masyarakat dapat memperoleh tambahan penghasilan dan memiliki kemampuan membeli komoditas kecil secara rutin guna memenuhi kebutuhan pokok keluarga berupa bahan sembako dan kebutuhan rutin lainnya. Adapun kemampuan membeli komoditas besar sebagai kemampuan untuk membeli barang di luar kebutuhan pokok sebagai kebutuhan sekunder. Sedikitnya masyarakat dapat membeli komoditas besar dengan cara mencicil.

6. Terlibat dalam pembuatan keputusan rumah tangga;

Dengan memiliki penghasilan, ibu rumah tangga menjadi lebih percaya diri dan dapat terlibat dalam pembuatan keputusan dalam keluarga termasuk dalam pemecahan masalah yang terjadi di dalam keluarga.

7. Meningkatkan interaksi antar kelompok masyarakat

Meningkatnya interaksi sosial sebagai dampak sosial dari pelaksanaan CSR. Menurut Walgito (2003:

57) interaksi sosial adalah hubungan antara individu satu dengan individu yang lain, individu satu dapat mempengaruhi individu yang lain atau sebaliknya, jadi terdapat adanya hubungan yang saling timbal balik.

8. Meningkatkan kerekatan sosial, kerja sama, rasa keakraban, kekompakan, saling percaya dan saling mendukung antar kelompok masyarakat.

Masyarakat dapat melakukan interaksi dengan sesama warga dengan baik, baik secara pribadi maupun antar kelompok masyarakat. Secara pribadi dapat berkomunikasi antar pribadi dalam aktifitas harian khususnya dalam hubungan ketetanggaan, maupun aktifitas di dalam kelompok kegiatan. Secara kelompok masyarakat dapat mengikuti kegiatan antar kelompok masyarakat, yaitu mengikuti atau menghadiri kegiatan PKK di wilayah setempat maupun kegiatan di kelurahan lain di Kecamatan Kiaracondong. Dimana sebelumnya masyarakat tidak banyak terlibat dalam berbagai kegiatan kemasyarakatan. Beberapa hasil yang diungkapkan diatas merupakan kondisi meningkatnya kapasitas masyarakat sebagai indikator dari pemberdayaan pada masyarakat miskin peserta pelatihan 


\section{Kebijakan: Jurnal Ilmu Administrasi \\ Volume 11, Nomor 1, Januari 2020 \\ E-ISSN: 2656-2820 \\ P-ISSN 1829-5762}

ketrampilan dalam pemberdayaan perempuan di Kecamatan Kiaracondong. Dengan demikian ditinjau dari empowerment index bantuan yang diberikan dalam kerangka CSR PT. Telkom di Kecamatan Kiaracondong Kota Bandung memberikan dampak kepada masyarakat.

Peran Pemerintah dalam pemberdayaan perempuan melalui CSR PT. Telkom dalam melaksanakan CSR program BUMN Membangun Desa dalam proses pelaksanaannya bekerja sama dengan beberapa Perguruan Tinggi. PT Telkom Indonesia menggandeng sejumlah perguruan tinggi dalam mengoptimalkan program BUMN Membangun Desa di 124 desa miskin di seluruh Indonesia. "Program BUMN Membangun Desa yang digelar Telkom tahun 2013 sebanyak 124 desa kategori tertinggal di sejumlah provinsi di Indonesia, 24 desa diantaranya di wilayah Jawa Barat," (http://www.jabarprov.go.id/index.php/news/6281/Telkom_Gandeng_Kampus_Bangun Desa) Sinergi dengan perguruan tinggi adalah untuk mengoptimalkan program pemberdayaan masyarakat desa dengan melakukan pendekatan kultural dan potensi daerah masing-masing. Di wilayah Priangan, Jawa Barat, Telkom menggandeng STIE Ekuitas, Unpad dan ITB dalam pengembangan program BUMN Membangun Desa tersebut. Tim pengajar dari perguruan tinggi dilibatkan dalam pembuatan survey dan mapping di desa yang masuk kategori miskin, namun memiliki potensi untuk berkembang. Adapun pemerintah yang terlibat dalam kegiatan ini adalah pemerintahan Kelurahan setempat, dengan partisipasinya dalam proses pelaksanaan kegiatan, sejak tahap survey, mapping, pelaksanaan pemberian bantuan, monitoring, dan evaluasi.

Berdasarkan hasil penelitian, unsur pemerintah baru sebatas pemerintah tingkat kelurahan, sementara dengan pemerintah tingkat kecamatan tidak terjalin kerja sama, bahkan tidak ada pemberitahuan dari pihak perusahaan. Sesungguhnya pemerintah memiliki kepentingan dalam isu CSR, sebagaimana dikemukakan oleh Steurer (2009) mengenai alasan kenapa pemerintah memiliki kepentingan di dalam isu CSR. Pertama hal tersebut sejalan dengan konsep pembangunan berkelanjutan (sustainable development). Motivasi pertama ini berkaitan dengan politik luar negeri seperti program pengembangan sumber daya manusia (human development program). Alasan kedua adalah, kebijakan CSR dianggap sebagai pelengkap yang menarik dalam peraturan yang lain misal di Indonesia dalam undang-undang Perseroan Terbatas, dalam hal ini pemerintah dapat menunjukkan kepeduliaanya pada isu social dan lingkungan meskipun peraturan tentang CSR ini hanya mendapatkan porsi yang sangat sedikit didalam undang-undang tersebut. Ketiga adalah, pelaksanaan CSR masih sebatas pada asas sukarela (voluntary basis) sehingga pemerintah perlu memberikan penekanan agar pelaksanaan CSR lebih mendapat fokus perhatian dari perusahaan. Alasan keempat adalah, banyak pendekatan dalam pelaksanaan CSR menggunakan konsep partnership program (program kemitraan) sehingga akan membuka potensi keterlibatan masyarakat secara luas dalam pembangunan berkelanjutan. Hal ini sangat berkaitan dengan pengelolaan hubungan dan peran dengan pemangku kepentingan secara luas misalnya bisnis, pemerintah dan masyarakat sipil.

Fox et al. (2002) Bank Dunia telah memberikan kategori peran pemerintah dalam mensupport CSR ke dalam lima kategori peran sektor public yang dapat di adopsi oleh pemerintah dalam isu CSR yaitu mandatory (peran legislasi), facilitating (missal; petunjuk dalam hal konten pelaporan CSR), partnering (proses penguatan dengan multi-stakeholder), dan endorsing (publikasi dan pemberian penghargaan). O"Rouke (2004) memberikan penjelasan lebih detail tentang kategori peran pemerintah diatas. Pertama, peran mandating adalah ketika pemerintah secara legal memberikan mandat melalui undang undang atau peraturan pemerintah. Sehingga pemerintah dapat melakukan pengawasan dari segi pelaporan CSR baik evaluasi laporan maupun melakukan cross check terhadap isi laporan. Kedua adalah facilitating ketika pemerintah memberikan suatu rujukan atau guidelines dalam pelaksanaan maupun pelaporan CSR dan penyebarluasan informasi CSR. Ketiga adalah 


\section{Kebijakan: Jurnal Ilmu Administrasi Volume 11, Nomor 1, Januari 2020 E-ISSN: 2656-2820 P-ISSN 1829-5762}

partnering yang mana pemerintah terlibat dalam proses promosi inisiatif kerjasama multistakeholder atau kerjasama dengan masing-masing perusahaan. Dengan kata lain pemerintah dapat menjadi fasilitator dialog antar pemangku kepentingan. Keempat adalah peran endorsing dalam hal pelaporan program CSR melalui usaha yang positif dalam kerangka transparansi. Pemerintah Indonesia melalui undang undang Perseroan Terbatas UU No 40 Tahun 2007 mengisyaratkan bahwa secara eksplisit peran yang dilakukan pemerintah adalah pada peran "mandating"e. Peran mandating yang dilakukan pemerintah juga tercermin pada peraturan Menteri Negara Badan Usaha Milik Negara (BUMN) Nomor 05/MBU/2007 tentang Program Kemitraan BUMN dengan Usaha Kecil Menengah (UKM )dan Program Bina Lingkungan (BL). Peran pemerintah dalam isu CSR sangatlah diperlukan melalui kebijakannya yang dapat dituangkan dalam undang-undang sebagai upaya untuk memberikan dorongan dan perhatian serius bagi dunia usaha agar memiliki motivasi yang kuat dalam konsistensi pelaksanaan program CSR yang baik. Peran pemerintah Indonesia sekarang ini masih sebatas peran yang memberikan mandat melalui peraturan perundangundangan yang hanya bagian kecil dari undang-undang Perseroan Terbatas (UU PT) tetapi lebih jauh lagi pemerintah seharusnya mampu berperan lebih dalam isu CSR misalnya tentang bagaimana berperan dalam facilitating role misalnya memfasilitasi kesepakatan teknis pelaporan CSR dengan seluruh stakeholder.

Dalam system pengawasan bagi pelaksanaan CSR di Indonesia, peran pemerintah masih jauh dari ideal, pemerintah diharapkan mampu berperan lebih dengan adanya transparansi pelaporan CSR melalui mekanisme audit CSR. Beberapa hal yang dapat dilakukan oleh pemerintah untuk pencapaian CSR yang dapat sejalan dengan isu pembangunan berkelanjutan adalah melalui peran-peran yang dituangkan dalam panduan World Bank seperti peran memfasilitasi, mendorong dan kemitraan yang dapat dituangkan dalam kebijakan pemerintah baik melalui undang undang CSR, peraturan pemerintah atau adanya lembaga yang berwenang dalam seluruh isu yang berkaitan dengan CSR. Pada pelayanan publik memfokuskan pada hubungan antara pembuat kebijakan dan organisasi publik. Good governance memfokuskan pada penyebaran model sosial normatif, politik, dan administrative governance oleh organisasi supranasional seperti World Bank. New public governance memfokuskan pada lima prinsip diantaranya: (a) social-political governance, (b) public policy governance, (c) administrative governance, (d) contract governance, (e) network governance. Pertama, socialpolitical governance memfokuskan relasi institusi dengan masyarakat. hubungan dan interaksi harus dipahami untuk memahami implementasi kebijakan publik. Kedua, public policy governance, memfokuskan pada bagaimana para elit pengambil kebijakan dan interaksi jaringan untuk membuat dan memutuskan proses kebijakan publik. Ketiga, administrative governance memfokuskan pada efektifitas aplikasi dari public administration untuk menyelesaikan masalah implementasi kebijakan publik abad 21. Keempat, contract governance memfokuskan pada kontrak dalam penyelenggaraan pelayanan publik sebagai upaya tanggung jawab pada pelayanan publik. Kelima, network governance memfokuskan pada mengorganisir diri terhadap jaringan interorganisasional. Fungsi dimana dengan atau tanpa pemerintah untuk menyediakan pelayanan publik. Semua perspektif teori governance diatas merupakan kontribusi penting pada pemahaman kita mengenai implementasi kebijakan publik dan penyelenggaraan pelayanan publik. Prinsip network governance, dimana pemerintah, masyarakat dan dunia usaha memiliki jaringan dan interaksi yang sinergik, untuk mengimplementasikan kebijakan diperlukan adanya kepemimpinan yang inovatif dan memiliki visi yang jelas, memperhatikan sistem nilai yang berlaku di masyarakat Kota Bandung, adanya kepercayaan, komitmen, sumberdaya, aturan, kepentingan publik serta pemerataan kesempatan. 


\section{Kebijakan: Jurnal Ilmu Administrasi \\ Volume 11, Nomor 1, Januari 2020 \\ E-ISSN: 2656-2820 \\ P-ISSN 1829-5762}

\section{SIMPULAN}

Peran yang dilakukan pemerintah belum maksimal,. Dalam hal legislasi, pemerintah masih sebatas memberikan porsi yang cukup sedikit perhatiannya untuk isu CSR seperti dapat kita lihat di ayat 74 undang-undang No 40 Tahun 2007. Hal tersebut belum secara maksimal menunjukkan peran facilitating, partnering maupun endorsing. Dalam peran mandating, penekanan memiliki program CSR pada perusahaan ekstraktif di Indonesia tersebut masih banyak kekurangan dalam hal control and legislation. Sebagai contoh, kondisi tidak adanya standar dalam pembuatan laporan CSR akan menimbulkan sebuah tendensi bahwa tidak adanya keseimbangan dalam hal penyampaian laporan CSR nantinya. Artinya bahwa tidak semua laporan yang diinginkan oleh pemangku kepentingan dalam isu CSR diberikan oleh perusahaan tersebut. Misalnya perusahaan tertentu akan lebih memiliki fokus perhatian yang cukup besar pada isu sosial karena perusahaan tersebut memiliki permasalahan pada aspek lingkungan. Dapat dikatakan bahwa tidak adanya kebijakan pemerintah dalam peran facilitating yaitu pemberian standar pelaporan CSR memperlihatkan bahwa perusahaan seringkali tidak siap dan tidak konsisten dalam pelaporan CSR yang mereka publikasikan. Lebih lagi akan terjadi kemungkinan tidak samanya implementasi di lapangan dengan pelaporan yang dibuat karena kelemahan dalam mekanisme kontrol dari pemerintah atau lembaga yang berwenang. Ada kontradiksi yang terjadi yaitu pemerintah sebagai lembaga yang telah memberikan mandat kepada perusahaan dalam melakukan program CSR tetapi pemerintah sendiri kesulitan dalam mengevaluasi mandat yang telah diberikan kepada perusahaan mengingat tidak ada kesamaan format atau standar pelaporan CSR.

Hal tersebut belum memperlihatkan secara rinci bagaimana implementasi CSR yang seharusnya perusahaan lakukan dan bagaimana standar laporan setelah perusahaan tersebut menjalankan CSR programnya. Idealnya pemerintah dapat memainkan peran dalam perumusan standar dalam årea CSR misalnya seperti environmental protection, health \& safety and employment rights. Terlebih lagi pemerintah dapat menciptakan kebijakan dan institutional framework misalnya dapat memberikan stimulus pada perusahaan dalam mencapai standar minimum pecapaian program CSR. Contoh lain peran yang dapat diambil pemerintah adalah memberikan insentif fiskal (pajak) terhadap perusahaan yang dengan baik menjalankanprogram tanggung jawab sosialnya. Peran-peran tertentu perlu ditingkatkan oleh pemerintah dengan kapasitasnya dalam isu CSR di Indonesia, misalnya dalam mandating di aspek pengawasan dan pemberian reward dan sanksi terhadap perusahaan. Peran kemitraan (partnership) harus secara nyata dilakukan sebagai bentuk penggerak dan mediator antara dunia usaha (perusahaan) dengan masyarakat dalam kerjasama-kerjasama strategis yang mampu meningkatkan benefit bagi masyarakat sekitar perusahaan dan secara jangka panjang dapat memberikan kontribusi bagi proses pembangunan berkelanjutan di Indonesia melalui keterlibatan dunia usaha.

Mengambil konsep dari Steurer (2009) setidaknya pemerintah harus memberikan penguatan pada kebijakan CSR di Indonesia sebagai upaya untuk; (1) Meningkatkan kesadaran dan membangun kapasitas dalam rangka tanggung jawab sosial perusahaan. Hal ini dikarenakan bahwa CSR adalah berdasar pada asas sukarela (voluntary basis); (2) Meningkatkan transparansi atas pelaksanaan CSR yang di mandatkan oleh undang-undang No 40 Tahun 2007 tentang tanggung jawab sosial perusahaan. Ketersediaan informasi tentang kinerja perusahaan dalam aspek ekonomi, sosial dan lingkungan dapat menjadi bahan pertimbangan bagi pemangku kepentingan seperti investor, pemerintah, karyawan, supplier dan konsumen sehingga mereka dapat menilai sejauh mana perusahaan tersebut memiliki program CSR yang baik dan berkelanjutan; (3) Memfasilitasi investasi sosial dalam rangka pembangunan berkelanjutan. Hal ini sejalan dengan Socially Responsible Investment (SRI); (4) Proses pembandingan (benchmarking atau best practice) bagi perusahaan atau 


\section{Kebijakan: Jurnal Ilmu Administrasi \\ Volume 11, Nomor 1, Januari 2020 \\ E-ISSN: 2656-2820 \\ P-ISSN 1829-5762}

negara lain di dunia dalam hal pelaksanaan dan pengawasan program CSR. Dalam hal yang lebih spesifik meliputi pemberian panduan pelaporan yang jelas bagi perusahaan dengan diawali dialog untuk kesepakatan tentang standar yang akan dijadikan rujukan.

Beberapa hal yang dapat dilakukan oleh pemerintah untuk pencapaian CSR yang dapat sejalan dengan isu pembangunan berkelanjutan adalah melalui peran-peran yang dituangkan dalam panduan World Bank seperti peran memfasilitasi, mendorong dan kemitraan yang dapat dituangkan dalam kebijakan pemerintah baik melalui undangundang CSR, peraturan pemerintah atau adanya lembaga yang berwenang dalam seluruh isu yang berkaitan dengan CSR di Indonesia. Pemerintah harus bisa mewujudkan dengan network governance memfokuskan pada mengorganisir diri terhadap jaringan interorganisasional. Fungsi dimana dengan atau tanpa pemerintah untuk menyediakan pelayanan publik dalam implementasi kebijakan publik dan penyelenggaraan pelayanan publik. Prinsip network governance, dimana pemerintah, masyarakat dan dunia usaha memiliki jaringan dan interaksi yang sinergik, untuk mengimplementasikan kebijakan diperlukan adanya kepemimpinan yang inovatif dan memiliki visi yang jelas, memperhatikan sistem nilai yang berlaku di masyarakat Kota Bandung, adanya kepercayaan, komitmen, sumberdaya, aturan, kepentingan publik serta pemerataan kesempatan.

\section{DAFTAR PUSTAKA}

Adi, Isbandi Rukminto. (2001). Pemberdayaan, Community Development dan Intervensi Komunitas (Pengantar pada Pemikiran dan Pendekatan Praktis). Jakarta LP. FE UI.

Alfitri, 2011, Community Development Teori Dan Aplikasi, Pustaka Pelajar, Yogyakarta.

Burns, Danny et al, 2004, Community Self Help, Anthony Rowe Ltd, Great Britain.

Chambers, Robert, 1987, Pembangunan Desa Mulai Dari Belakang, LP3ES, Jakarta Conyers, Diana.

Perencanaan Sosial di Dunia Ketiga : Suatu pengantar. Penerjemah Susetiawan dan Affan Gafar. Yogyakarta : Gajah Mada University Press. 1991.

Cummins, Linda K, et.al, 2011, Policy Practice For Social Workers, New Strategies for New Era, Pearson, Boston.

David Katamba, 2012, Principles of Corporate Social Responsibility (CSR), A Guide for student and practicing managers in developing and emerging countries, Strategic Book and Publishing, Houston

Dwi Kartini, 2009, Corporate Social Responsibility, Transformasi konsep Sustainability Management Dan Implementasi Di Indonesia, Refika Aditama, Bandung.

Elkington, John (1998), Cannibals With Forks: The Triple Bottom Line in 21st Century Business, Gabriola Island, BC: New SocietyPublishers

Elliot, Doren. "Social Work and social Development : Toward an Integrative Model for Social Work Pratice". International Social Work. 1993..

Fox, T., Ward, H., Howard, B. (2002). Public Sector Roles in Strengthening Corporate Social Responsibility: A Baseline Study. The World Bank.

Gunawan, Alex, 2008, Membuat Program CSR Berbasis Pemberdayaan Partisipatif, buku online

Jeanette Brejning, 2012, Corporate Social Responsibility, The Historical and Contemporary Role of CSR in The Mixed Economi of Welfare, University of Bristol, UK

Junaidi, Muhammad, 2013, Korporasi Dan Pembangunan Berkelanjutan, Alfabeta, Bandung

Kenny, Susan, 2007, Developing Communities For The Future, Thompson, South Melbourne

Komara, Eko, 2013, Menakar CSR (Memetakan Potensi Pendanaan CSR Dan Peluang Kolaborasi Dengan CSO), HIVOS, IBCSD, Jembatan Tiga, Penabulu Alliance. Kotler, Phillip \&, Nancy, 


\section{Kebijakan: Jurnal Ilmu Administrasi}

Volume 11, Nomor 1, Januari 2020

E-ISSN: 2656-2820

P-ISSN 1829-5762

2005, Corporate Social Responsibility, Doing The Most Good for Your Company and Your Cause, John Wiley \& Son, New Jersey.

Kurniati, 2011, Panduan Praktis Pengelolaan CSR (Corporate Social Responsibility), Salemba Biru, Yogyakarta

Marind B and Renate Mayntz. 1991. Policy Networks: Empirical Evidence and Theoretical Considerations,

Mark S. Schwartz, 2011, Corporate Social Responsibility; An Ethical Aproach, Broadview Press, Canada

Milton G Thackeray et.al, 1994, Introduction To Social Work, Prentice Hall International Editions, Englewood Clis, NJ

Moleong, Lexy J, 1994, Metodologi Penelitian Kualitatif, Remaja Rosdakarya, Bandung. Morales, A. T. \& Sheafor, B. W., 199, Social Work: A profesion of Many Faces, Allyn and Bacon, Boston

Nasikun, Dr. 1996. Urbanisasi dan Kemiskinan di Dunia Ketiga. PT. Tiara Wacana.Yogyakarta.

Norhadi, 2011, Corporate Social Responsibility, Graha Ilmu, Semarang

Noveria, Mita, 2011, Pertumbuhan Penduduk Dan kesejahteraan, LIPI Press, Jakarta

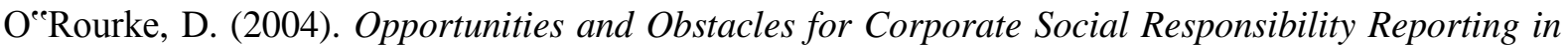
Developing Countries. The World Bank and International Finance Corporation. OECD, 2004, OECD Principles of Corporate Governance, OECD Publication Service.

Payne, Malcolm, (2005), Modern Social Work Theory, Palgrave Macmillan, New York. Rudito Bambang, 2013, CSR (Corporate Social Responsibility, Rekayasa Sains, Bandung Rubin, Herbert J, and Rubin, Irene S (2000), Community Organizing and Development, Allyn and Bacon, Massachusetts

Siporin, M., 1975, Introduction to Social Work Practice, Mac Millan, New York. Soedarmayanti, 2012, Good Governance \& Good Corporate Governance, Mandar Maju, Bandung

Straussner, Shulamith Lala Ahenberg, 1989, Occupational Social Work Today, An Overview, The Haworth Press, New York

Straussner, Shulamith Lala Ahenberg (2002), Urban Social Work, Allyn and Bacon, New York

Steurer, R. (2009). The role of governments in corporate social responsibility: characterising public policies on CSR in Europe. Springer Science+Business Media, LLC.

Suharto, Edi, (2009), Pekerjaan Sosial Di Dunia Industri, Alfabeta, Bandung, (2010), CSR \& Comdev Investasi Kreatif Perusahaan Di Era Globalisasi, Alfabeta, Bandung

Suharto, Ign 2010, Program Community Development Dan Peningkatan Kesejahteraan, Unpad Pres, Bandung

Suhartini, et. Al, 2005, Model-Model Pemberdayaan Masyarakat, LkiS Pelita Aksara, Yogyakarta.

Wahyudi, Isa et.al, 2011,Corporate Social Responsibility : Prinsip, Pengaturan \& Implementasi, Setara Press \& Inspire, Malang

Wibisono, Yusuf, 2007, Membedah Konsep dan Aplikasi CSR, Fasco Publishing, Jakarta

Zubaedi (2016), Pengembangan Masyarakat Wacana dan Praktik, Prenadamedia Group, Jakarta. 